\title{
HIV disease progression compared by linkage status in Rwanda and Zambia
}

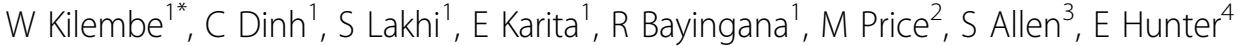 \\ From AIDS Vaccine 2012 \\ Boston, MA, USA. 9-12 September 2012
}

\section{Background}

Recently HIV infected individuals are followed up at Rwanda-Zambia HIV Research Group (RZHRG) sites to establish markers of disease progression. Here we compare disease progression between seroconverters infected by their spouses (linked transmission) to those infected by non-spousal partners (unlinked transmission) where a greater fraction of individuals are infected by multiple virus variants.

\section{Methods}

Seroconverters (SC) were identified from HIV discordant couples enrolled from the Couples' VCT program into a prospective cohort study. Linkage of transmission was established by comparing viral DNA sequences in the SC to that of the suspected index partner. SCs were followed up to six years to collect clinical and laboratory data. Data analysis using STATA was done on CD4 and viral load trajectories and a comparison of disease progression with respect to time to endpoints of CD4 $<350$ cells/uL and initiation of ARVs. Log rank test of equality for survival function was performed for each endpoint and p-values calculated.

\section{Results}

From February 2006 to December 2011, 88 unlinked and 225 linked transmissions were identified. Across all RZHRG sites, SC males represented 56\% of the unlinked and $55 \%$ of the linked group. Overall mean age at seroconversion was 33 years and $69 \%$ of HIV transmissions were acute infections (identified within 90 days of infections). Mean CD4 count and viral load at specified time points during a six year follow up period of the two groups were similar. Disease progression in the two groups (CD4

${ }^{1}$ Rwanda Zambia HIV Research Group, Lusaka, Zambia

Full list of author information is available at the end of the article
$<350$ cell/uL or initiation of ARVs) showed no significant difference $(\mathrm{p}=0.21$ and $\mathrm{p}=0.26)$ respectively.

\section{Conclusion}

Despite the fact that previous studies have shown that there is faster disease progression in individuals who were infected by multiple genetic variants from their partner, we show here that linkage status does not predict HIV disease progression in HIV seroconverting couples.

\section{Author details}

${ }^{1}$ Rwanda Zambia HIV Research Group, Lusaka, Zambia. ${ }^{2}$ International AIDS Vaccine Initiative, San Fransisco, CA, USA. ${ }^{3}$ Emory University School of Medicine, Atlanta, GA, USA. ${ }^{4}$ Emory Vaccine Center and Yerkes Primate Center, Atlanta, GA, USA.

Published: 13 September 2012

doi:10.1186/1742-4690-9-S2-P161

Cite this article as: Kilembe et al:: HIV disease progression compared by linkage status in Rwanda and Zambia. Retrovirology 2012 9(Suppl 2):P161.

Submit your next manuscript to BioMed Central and take full advantage of:

- Convenient online submission

- Thorough peer review

- No space constraints or color figure charges

- Immediate publication on acceptance

- Inclusion in PubMed, CAS, Scopus and Google Scholar

- Research which is freely available for redistribution 